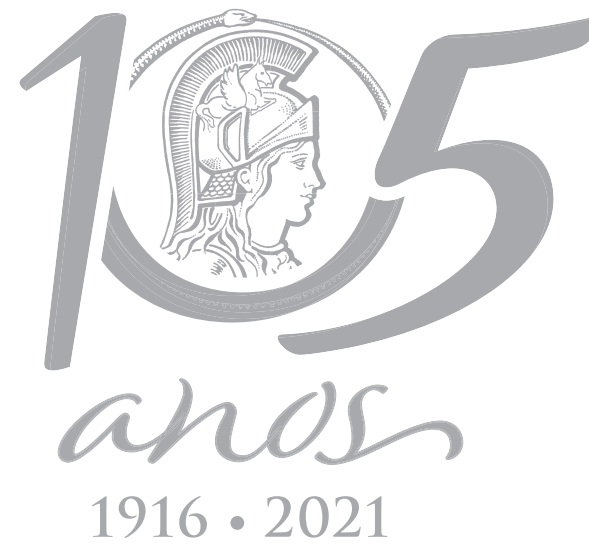

$1916 \cdot 2021$

\title{
ECOSYSTEMS
}

\section{Environmental and phylogenetic aspects affect in different ways the acoustic niche of a frog community in southeastern Brazil}

\author{
MARIA CAROLINA R. MANZANO \& RICARDO J. SAWAYA
}

\begin{abstract}
One of the most important resources for reproduction in frogs is the acoustic space since the advertisement call, which is mostly used to attract females, may suffer interference when the acoustic space is widely filled. Other important resources are calling sites and adequate climatic conditions. We analyzed herein three dimensions of the acoustic niche of anurans (advertisement calls, calling period, and calling sites). We recorded 11 calling species of frogs in a tropical community. Species richness was negatively related to temperature, and daily activity was positively related to humidity. We also observed a greater niche overlap than expected by chance in calling periods. These results indicate that the climatic conditions should act as an environmental filter, synchronizing the calling period. The calling site was not shared among species, and no clear pattern of substrate use was observed. Regarding the acoustic dimension, we observe a phylogenetic signal in the dominant frequency of advertisement calls. Hierarchical cluster analysis also indicated a congruence between acoustic distances and phylogenetic relationships. Therefore, the dominant frequency of advertisement calls was constrained by phylogenetic relationships, indicating that it affects the partitioning and use of acoustic resources, an important dimension in reproductive activity in anurans.
\end{abstract}

Key words: Atlantic Forest, bioacoustics, daily activity, habitat use, Niche overlap.

\section{INTRODUCTION}

The Neotropical region has the largest diversity of reproductive modes of anuran amphibians (Haddad \& Prado 2005, Crump 2015). More than 30 anuran reproductive modes have been described in the last decades in this region (Haddad \& Prado 2005, Crump 2015), 11 of which for the family Hylidae only in the Atlantic Forest, from 12 modes known for this clade (Haddad \& Sawaya 2000). Reproductive aspects have been more studied in anurans, since reproduction is one of the most remarkable features of this vertebrate group (Wells 2007).

Frogs can aggregate to form choruses of calling males, mostly during the rainy and warm seasons (Wells 1977, Prado et al. 2005). In this case, the acoustic space can become a limited resource since calling males need to deal with competitive pressure while receivers need to decipher messages in a noisy environment (Grafe 2005). For this group, advertisement calls are an important feature for reproduction, being considered a relevant mechanism of reproductive isolation and sexual selection since it is used for species identification, sexual receptivity and even transmitting information about the calling male (Wells 1977, 2007, Haddad et al. 1990).

Other important resources are calling sites and adequate temperature and humidity conditions for vocalizing. The climatic conditions 
even contribute to the aggregation of calling males in chorus, regulating their activity and acoustic parameters (e.g. Lingnau \& Bastos 2007, Ximenez \& Tozetti 2015). The calling sites are also widely studied, and the spatial partitioning is documented in different anuran communities (Rossa-Feres \& Jim 2001, Martins et al. 2006, Vasconcelos \& Rossa-Feres 2008), mainly related to environmental heterogeneity for example. Therefore, it has been suggested that species coexistence is allowed by differential use of acoustic space and calling sites, besides temporal partitioning during breeding activity (Rossa-Feres \& Jim 2001, Prado et al. 2005, Martins et al. 2006, Vasconcelos \& Rossa-Feres 2008).

Hutchinson (1957) defined ecological niche as a multidimensional space mostly related to resource use. Niche overlap occurs when species share different niche dimensions in a similar way (Wells 2007), and resource partitioning has been documented as a relevant factor for species coexistence and reproductive success in anuran ecological communities (e.g. Conte \& Machado 2005, Grafe 2005, Prado \& Pombal 2005). Moreover, reproductive aspects and species coexistence are prominent structuring factors of diversity for this group (cf. Haddad 1991, Rossa-Feres \& Jim 2001, Bertoluci \& Rodrigues 2002, Conte \& Machado 2005). If resource partitioning is an important pattern in structuring communities, a high overlap in one niche dimension should be compensated by a low overlap in other dimensions (Schoener 1974, Vasconcelos \& Rossa-Feres 2008), and complete niche overlapping would be uncommon in nature (Rossa-Feres \& Jim 2001).

The acoustic niche of anurans can be summarized in three dimensions according to some studies (e.g. Sinsch 2012, Guerra et al 2020): the acoustic dimension, estimated here by the dominant frequency of advertisement calls, mostly used to attract females and considered important to species recognition (Wells 1977, 2007, Haddad et al. 1990); the temporal dimension, or the daily period of calling activity; and calling site, measured here by perch height and distance from the margin. The acoustic niche can be influenced differently by environmental and phylogenetic factors.

Environmental factor such as humidity and temperature may be related to survival, diversity and reproductive activity in frogs, since this group cannot control body temperature through metabolism and must seek specific microhabitats and microclimatic conditions (Well 2007, Eterovick \& Sazima 2000, Haddad \& Prado 2005, Silva et al. 2012, Crump 2015). Besides that, other environmental aspects such as habitat heterogeneity and microhabitats availability can also affect the reproductive activity and anuran community structure in different ways (Parris 2004, Silva et al. 2012, Foerster \& Conte 2018, Figueiredo et al. 2019), contributing to the availability of the calling and oviposition sites for example.

Biotic factors including phylogenetic relationships and species composition can also influence the acoustic niche of anurans. Acoustic competition among individuals may lead to slight adjustments in call variables (Bosch \& Márquez 1996, Grafe 2005), in order to occupy empty niche spaces (Krause 1987, Pijanowski et al. 2011). In this case, the acoustic parameters may be more different among species. Opposite to that, in chorus systems species can form communication networks, so that they present call signals mostly similar to each other (Tobias et al. 2014). Closely related species can also show more similar advertisement calls if niche conservatism is present (Wiens \& Graham 2005, Wiens et al. 2010). In that way different process such as competition for resources, environmental filters and phylogenetic relationships can 
influence the observed patterns, whether they are more or less overlapped than expected by chance. We analyzed and explored herein three dimensions of the acoustic niche of anurans in a tropical community, comprising acoustic, temporal, and spatial features.

\section{MATERIALS AND METHODS}

\section{Study site}

We carried out the study in a natural and permanent pond in the Reserva Biológica Municipal da Serra do Japi (RBMSJ) located in Jundiaí municipality, São Paulo State,

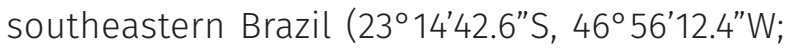
datum = WGS84), an area of remnants of Atlantic Forest, totaling 2071.2 hectares. The pond presents 45 meters of perimeter, an average canopy cover of $33.3 \%$, and $74.7 \%$ of water surface covered by vegetation. It varies in depth between 1 and $3 \mathrm{~m}$ and is surrounded by dense and secondary vegetation. The Atlantic Forest is considered a biodiversity hotspot (Myers et al. 2000, Resende et al. 2018), with one of the highest levels of amphibian endemism around the world (Haddad \& Prado 2005, Haddad et al. 2013, Rossa-Feres et al. 2011). It is also one of the most threatened morphoclimatic domains in Brazil, with only $11 \%$ to $28 \%$ of its original coverage remaining (Ribeiro et al. 2009, Resende et al. 2018). The mean temperature throughout the year varies between $11.8^{\circ} \mathrm{C}$ to $15.3^{\circ} \mathrm{C}$ in the coldest month, and $18.4^{\circ} \mathrm{C}$ to $22.2^{\circ} \mathrm{C}$ in the warmest month. Monthly rainfall varies between $250 \mathrm{~mm}$ in the summer to $41 \mathrm{~mm}$ in the winter (Pinto 1992).

\section{Data collection}

We collected field data from September 2015 to March 2016, during the rainy season when most anuran species breed, from dusk (5:00 p.m.) to sunrise (6:00 a.m.), with a minimum of three days per month, totalizing 23 days of fieldwork. Vocalization periods were recorded by estimating the number of calling individuals of each species, in each of the three-hour intervals sampled. We then estimated abundance of each species in five different hour intervals: 5 p.m., 8 p.m., 11 p.m., 2 a.m. and 5 a.m. (Table I). These values were estimated by walking around the pond and searching visually and acoustically the active males. We recorded the advertisement call of calling males of 11 frog species through a Sennheiser ME66/k6 directional microphone coupled to a Marantz PMD 620 digital recorder. The directional microphone was positioned at a distance between 0.5 and $1 \mathrm{~m}$ from males in calling activity and set at a $48 \mathrm{kHz}$ sample rate (16-bit audio depth and wav format). We also measured the distance of the recorded males from the pond margin, as well as perch height from the ground (Table I).

For the acoustic dimension we considered dominant frequency, defined as the frequency with the highest sound energy (sensu Köhler et al. 2017) and call duration. We analyzed all calls recorded in wav format in Raven Pro 64 software with these spectrogram parameters: window type Hann, window size 256 samples, 3dB filter bandwidth of $270 \mathrm{~Hz}, 50 \%$ overlap, DFT size 512 samples and grid spacing of $93.8 \mathrm{~Hz}$ (v1.5, Cornell Lab of Ornithology (2014), Bioacoustics Research Program, Ithaca, NY). One to 10 individuals of each species were analyzed, including up to five notes from each male (Table I), according to the availability of males in the pond. We collected for each recorded individual air and water temperature to the nearest $0.1^{\circ} \mathrm{C}$, and relative air humidity to the nearest $1 \%$ (Delmhorst HT-000 thermohygrometer). 
Table I. Three different dimensions of reproductive niche for 11 species of anuran amphibians in a permanent pond in Reserva Biológica Municipal da Serra do Japi (RBMSJ), Jundiaí municipality, São Paulo State, Brazil. Species (number of males; number of notes analyzed), mean ( \pm SD) of dominant frequency (in Hertz), call duration (in seconds), height from the ground and distance from the margin of calling site (in centimeters) and mean abundance $( \pm S D)$ of estimated males calling in each period of daily activity.

\begin{tabular}{|c|c|c|c|c|c|c|c|c|c|}
\hline \multirow[b]{2}{*}{ Species } & \multirow{2}{*}{$\begin{array}{l}\text { Dominant } \\
\text { frequency } \\
(\mathrm{Hz})\end{array}$} & \multirow{2}{*}{$\begin{array}{c}\text { Call } \\
\text { duration } \\
\text { (s) }\end{array}$} & \multicolumn{2}{|c|}{ Calling site } & \multicolumn{5}{|c|}{ Calling period (abundance) } \\
\hline & & & $\begin{array}{l}\text { Height } \\
\text { (cm) }\end{array}$ & $\begin{array}{l}\text { Distance } \\
\quad(\mathrm{cm})\end{array}$ & 5p.m. & 8p.m. & 11p.m. & 2a.m. & 5a.m. \\
\hline $\begin{array}{c}\text { Aplastodiscus } \\
\text { leucopygius }(5 ; 18)\end{array}$ & $2260.4 \pm 44.2$ & $0.19 \pm 0.03$ & $\begin{array}{l}221.7 \pm \\
70.4\end{array}$ & $\begin{array}{l}370 \pm \\
323.57\end{array}$ & $\begin{array}{c}0.3 \pm \\
0.8\end{array}$ & $\begin{array}{l}2.4 \pm \\
1.3\end{array}$ & $\begin{array}{c}2.2 \pm \\
1.9\end{array}$ & $\begin{array}{l}0.5 \pm \\
0.5\end{array}$ & 0 \\
\hline $\begin{array}{l}\text { Bokermannohyla } \\
\text { luctuosa }(2 ; 10)\end{array}$ & $1762.5 \pm 96.8$ & $\begin{array}{c}0.56 \pm \\
0.08\end{array}$ & 140 & 20 & 0 & 0 & 0 & 4 & $\begin{array}{l}1.5 \pm \\
1.5\end{array}$ \\
\hline $\begin{array}{c}\text { Boana bischoffi }(7 ; \\
34)\end{array}$ & $\begin{array}{l}1665.4 \pm \\
144.2\end{array}$ & $0.12 \pm 0.1$ & $\begin{array}{l}58.08 \\
\pm 48.5\end{array}$ & $\begin{array}{l}154.73 \pm \\
257.69\end{array}$ & 0 & $\begin{array}{l}6.7 \pm \\
3.7\end{array}$ & $\begin{array}{l}8.8 \pm \\
4.6\end{array}$ & $\begin{array}{c}8.8 \pm \\
3.7\end{array}$ & $\begin{array}{c}0.7 \pm \\
0.6\end{array}$ \\
\hline Boana faber $(7 ; 35)$ & $1098.2 \pm 66.6$ & $0.1 \pm 0.02$ & $\begin{array}{c}19.6 \pm \\
40.2\end{array}$ & $\begin{array}{l}-36.87 \pm \\
113.78\end{array}$ & 0 & $\begin{array}{c}5.6 \pm \\
2.2\end{array}$ & $\begin{array}{l}3.5 \pm \\
1.6\end{array}$ & $\begin{array}{l}2.6 \pm \\
1.5\end{array}$ & $\begin{array}{c}0.6 \pm \\
0.7\end{array}$ \\
\hline $\begin{array}{c}\text { Boana prasina (10; } \\
50)\end{array}$ & $\begin{array}{l}1556.2 \pm \\
108.8\end{array}$ & $0.3 \pm 0.05$ & $\begin{array}{c}76.4 \pm \\
48.6\end{array}$ & $\begin{array}{c}120.73 \pm \\
117.01\end{array}$ & 0 & $\begin{array}{l}5.9 \pm \\
2.6\end{array}$ & $\begin{array}{l}9.6 \pm \\
7.8\end{array}$ & $\begin{array}{c}4.2 \pm \\
4.7\end{array}$ & $\begin{array}{c}0.5 \pm \\
0.8\end{array}$ \\
\hline $\begin{array}{l}\text { Dendropsophus } \\
\text { minutus }(6 ; 28)\end{array}$ & $\begin{array}{l}5055.8 \pm \\
241.9\end{array}$ & $0.18 \pm 0.03$ & $\begin{array}{l}43.6 \pm \\
24.7\end{array}$ & $\begin{array}{l}-32.64 \pm \\
129.09\end{array}$ & $\begin{array}{c}0.5 \pm \\
0.9\end{array}$ & $\begin{array}{c}17.6 \pm \\
6.6\end{array}$ & $\begin{array}{l}4.6 \pm \\
2.2\end{array}$ & $\begin{array}{l}3.7 \pm \\
2.8\end{array}$ & $\begin{array}{c}0.4 \pm \\
0.7\end{array}$ \\
\hline $\begin{array}{l}\text { Dendropsophus } \\
\text { sanborni }(4 ; 20)\end{array}$ & $\begin{array}{l}5250 \pm \\
136.06\end{array}$ & $\begin{array}{l}0.05 \pm \\
0.003\end{array}$ & $\begin{array}{c}40.6 \pm \\
26.2\end{array}$ & $\begin{array}{l}-106.25 \pm \\
145.56\end{array}$ & 0 & $\begin{array}{l}2.8 \pm \\
2.3\end{array}$ & $1 \pm 1.4$ & $\begin{array}{l}0.4 \pm \\
0.5\end{array}$ & 0 \\
\hline $\begin{array}{l}\text { Phyllomedusa } \\
\text { burmeisteri }(1 ; 5)\end{array}$ & 1125 & $0.26 \pm 0.02$ & 200.2 & 106.9 & 0 & $\begin{array}{c}1.3 \pm \\
1.2\end{array}$ & 1 & 1 & $\begin{array}{c}0.3 \pm \\
0.6\end{array}$ \\
\hline $\begin{array}{l}\text { Physalaemus cuvieri } \\
\qquad(7 ; 35)\end{array}$ & $\begin{array}{l}819.6 \pm \\
364.05\end{array}$ & $0.28 \pm 0.03$ & 0 & $\begin{array}{l}-49.96 \pm \\
55.09\end{array}$ & $\begin{array}{l}0.3 \pm \\
0.5\end{array}$ & $\begin{array}{l}5 \pm \\
0.9\end{array}$ & $\begin{array}{c}1.3 \pm \\
0.8\end{array}$ & $\begin{array}{c}0.8 \pm \\
0.7\end{array}$ & $\begin{array}{c}0.3 \pm \\
0.5\end{array}$ \\
\hline Rhinella icterica (2; 5) & $600 \pm 83.8$ & $5.51 \pm 1.15$ & $\begin{array}{c}8.5 \pm \\
14.4\end{array}$ & $\begin{array}{l}-21.88 \pm \\
30.41\end{array}$ & $\begin{array}{c}0.2 \pm \\
0.4\end{array}$ & $\begin{array}{l}2.7 \pm \\
3.3\end{array}$ & $\begin{array}{l}1.2 \pm \\
1.8\end{array}$ & $\begin{array}{l}1.8 \pm \\
1.6\end{array}$ & $\begin{array}{c}1.4 \pm \\
1.8\end{array}$ \\
\hline Scinax hayii $(7 ; 35)$ & $\begin{array}{l}2758.9 \pm \\
929.3\end{array}$ & $0.26 \pm 0.05$ & $\begin{array}{c}85.5 \pm \\
36.1\end{array}$ & $\begin{array}{l}149.13 \pm \\
54.68\end{array}$ & 0 & $\begin{array}{l}7.4 \pm \\
6.6\end{array}$ & $\begin{array}{c}5.7 \pm \\
4.8\end{array}$ & $\begin{array}{c}8.7 \pm \\
8.4\end{array}$ & $\begin{array}{c}0.1 \pm \\
0.4\end{array}$ \\
\hline
\end{tabular}

\section{Data analysis}

All analyzes were done in the software R (v3.4.4, R Core Team (2018), R Foundation for Statistical Computing, Vienna, Austria). We tested the influence of air temperature and air humidity (independent variables) on species richness (number of different species) and abundance (total number of individuals; dependent variables) by linear multiple regressions in package "stats".

The niche overlap was tested by a null model approach (Gotelli \& Ellison 2013). Input data listed the 11 species in lines and resource categories in columns, considering presence and absence. The resources used by each species was characterized as calling site (calling site height, categorized in $0 \mathrm{~cm}, 0-150 \mathrm{~cm}, 50$ $100 \mathrm{~cm}, 100-150 \mathrm{~cm}, 150-200 \mathrm{~cm}$ and above 200 $\mathrm{cm}$ ), advertisement calls (dominant frequency in Hertz, categorized in 0-1000 Hz, $1000-2000 \mathrm{~Hz}$, 2000-3000 Hz and 3000-5000 Hz), and call activity (abundance of each species in five different hour intervals; Table I). We used the algorithm RA3 and Pianka's overlap index to implent 1000 
randomizations in package "EcosimR" ( $v$ 0.1.0, Gotelli et al. 2015).

In order to determine the influence of environmental variables and phylogenetic relationships in reproductive aspects, we performed partial mantel tests for dissimilarity matrices in package "vegan" (v2.5-5, Oksanen et al. 2019), including three matrices: phylogenetic distances, environmental distances and niche distances (considering three aspects of the reproductive niche as calling site, advertisement call and calling period). We estimated phylogenetic relationships and corresponding distances by pruning the 11 species in our community from a recent phylogenetic hypothesis including virtually all living species of amphibians (Jetz \& Pyron 2018) in package "adephylo" (v1.1-11, Jombart et al. 2010) using patristic distances. The environmental distance matrix was based on recorded data of air humidity, water temperature and air temperature, using Bray-Curtis distances. The three pairwise niche distance matrices were based on aspects of calling site (using Euclidean distances), advertisement calls and calling period (using Bray-Curtis distances; see Table I). The acoustic distance matrix was based on dominant frequency of advertisement calls. The calling site distance matrix was based on calling site height (in centimeters) and margin distance (in centimeters). The calling period distance matrix was based on abundance of each species on each one of the five-time period of data collection.

We also tested the phylogenetic signal of dominant frequency of advertisement call in “phylosignal" package (v1.2.1, Keck et al. 2016). The phylogenetic signal is the tendency for related species to resemble each other more than a species drawn at random from the species pool (Blomberg \& Garland 2002). The presence of phylogenetic signal rejects the null hypothesis, that the continuous attribute tested is distributed independent of the distance between species in the phylogeny (Keck et al. 2016). We performed a hierarchical cluster analysis in "ape" package (v5.1, Paradis et al. 2004) with variables of the advertisement call (dominant frequency and call duration), in order to understand to what extent advertisement calls reflects the phylogeny.

\section{RESULTS}

We recorded 11 species in calling activity belonging to eight genera and five families. Seasonal abundance considering all species varied between 45 and 79 individuals per day, and species richness varied from six to 10 species (Figure 1a). Species richness was negatively related to seasonal variation of air temperature $(F=4.33 ; d f=7 ; P=0.043$; see Figure $1 \mathrm{a}, \mathrm{b})$. Considering all collection days in the field, a peak in daily activity was observed in 8 p.m. period, followed by 11 p.m. and 2 a.m., with much lower abundance of calling males around 5 a.m. (Figure 1c). Daily activity was positively related to relative air humidity (see Figures 1c, d; F = 13.73; $\mathrm{df}=2 ; P=0.039$ ).

\section{Niche overlap}

We observed a greater overlap than expected by chance in calling period $(P<0.001$; Table II). Most species concentrate calling activity mainly in 8:00 p.m. period, but also in 11 p.m. and 2:00 p.m. (see Table I; Figure 1c). There was no niche overlap in calling site and dominant frequency, with observed means similar to those expected by null models $(P=0.81$ and $P=0.83$ respectively; Table II). 

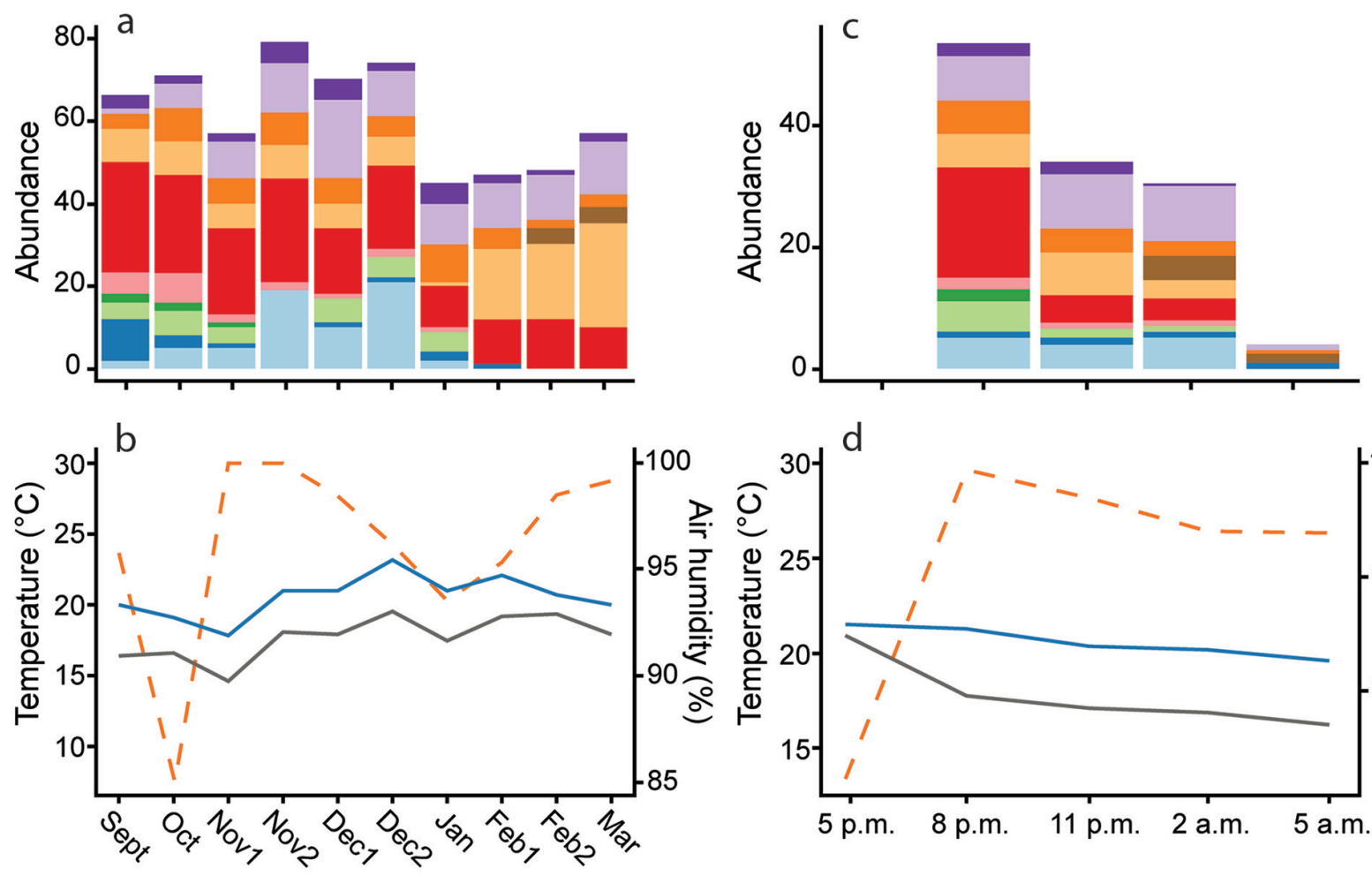

Sampling (months)

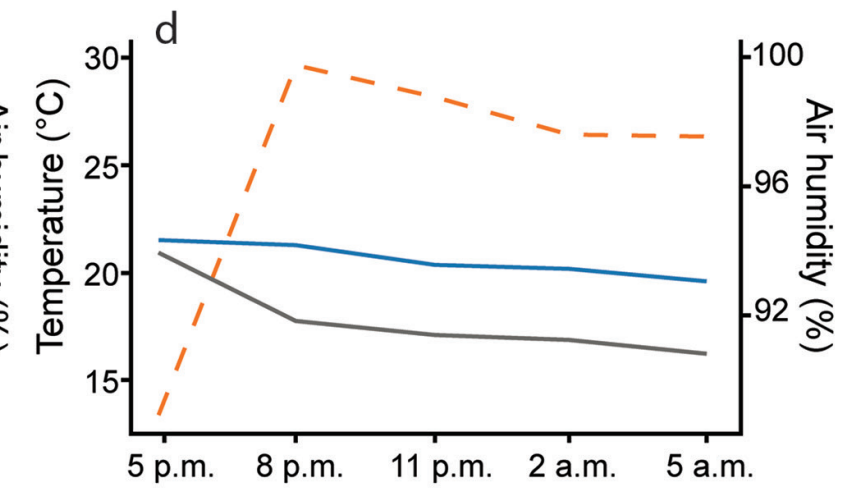

\section{Sampling (daily periods)}

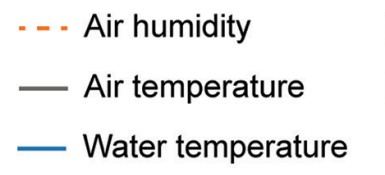
A. leucopygius
B. bischoffi
$B$ faber

B. luctuosa
B. prasina
D. minutus

D. sanborni

S. hayii

P. burmeisteri

R. icterica

Figure 1. Species richness and abundance variation of 11 amphibian species in a permanent pond in Reserva Biológica Municipal da Serra do Japi (RBMSJ), Jundiaí municipality, São Paulo State, Brazil. (a) Total number of individuals in calling activity throughout the reproductive season, with species corresponding to different colors. (b) Variation of mean air humidity and air and water temperatures throughout the reproductive season. (c) Average number of individuals in calling activity in different night periods. (d) Variation of mean air humidity and air and water temperatures throughout the reproductive season different night periods. Orange dashed line $=$ air humidity; grey line = air temperature; blue line = water temperature. Genera corresponds to: $A$ plastodiscus ( $A$. leucopygius), Boana (B. bischoffi, B. faber, B. prasina), Bokermannohyla (B. luctuosa), Dendropsophus (D. minutus, D. sanborni), Phyllomedusa (P. burmeisteri), Physalaemus (P. cuvieri), Rhinella (R. icterica), and Scinax (S. hayii).

Table II. Reproductive niche overlap among 11 amphibian species in a permanent pond in Reserva Biológica Municipal da Serra do Japi (RBMSJ), Jundiaí municipality, São Paulo State, Brazil. Observed means for each niche dimension (calling period, calling site, dominant frequency) and estimated mean of 1000 null models. Calling period with greater overlap (in bold) was the only niche dimension different than ones expected by chance.

\begin{tabular}{|c|c|c|c|}
\hline Aspects of reproductive niche & Observed mean & Estimated mean & P-value \\
\hline Calling period & 0.78 & 0.53 & $\mathbf{0 . 0 0 1}$ \\
\hline Calling site & 0.24 & 0.28 & 0.80 \\
\hline Dominant frequency & 0.24 & 0.20 & 0.83 \\
\hline
\end{tabular}




\section{Phylogenetic influence}

The phylogenetic distances of species were not related to calling period or calling site distances $(r=-0.002 ; P=0.47$; and $r=0.13 ; P=$ 0.25 , respectively). Phylogenetic distances were related to acoustic distances $(r=0.53 ; P=0.001)$ represented by dominant frequency. Dominant frequencies showed phylogenetic signal, with significant local positive autocorrelation value $(P>0.05)$ for Scinax hayii, Dendropsophus minutus and D. sanborni, and a significant local negative autocorrelation for Rhinella icterica and Physalaemus cuvieri (Figure 2).

Hierarchical cluster analysis showed congruence between acoustic distances and phylogenetic relationships in two clades: Dendropsophus minutus + D. sanborni, and Rhinella icterica + Physalaemus cuvieri (Figure 3).

\section{DISCUSSION}

We explored how different dimensions of acoustic niche are shared by frogs species in a tropical community. One of the niche dimensions, calling period activity, overlapped more than expected by chance (see Table II). Two other niche dimensions analyzed, dominant frequency of advertisement call and calling site, were not significantly different from

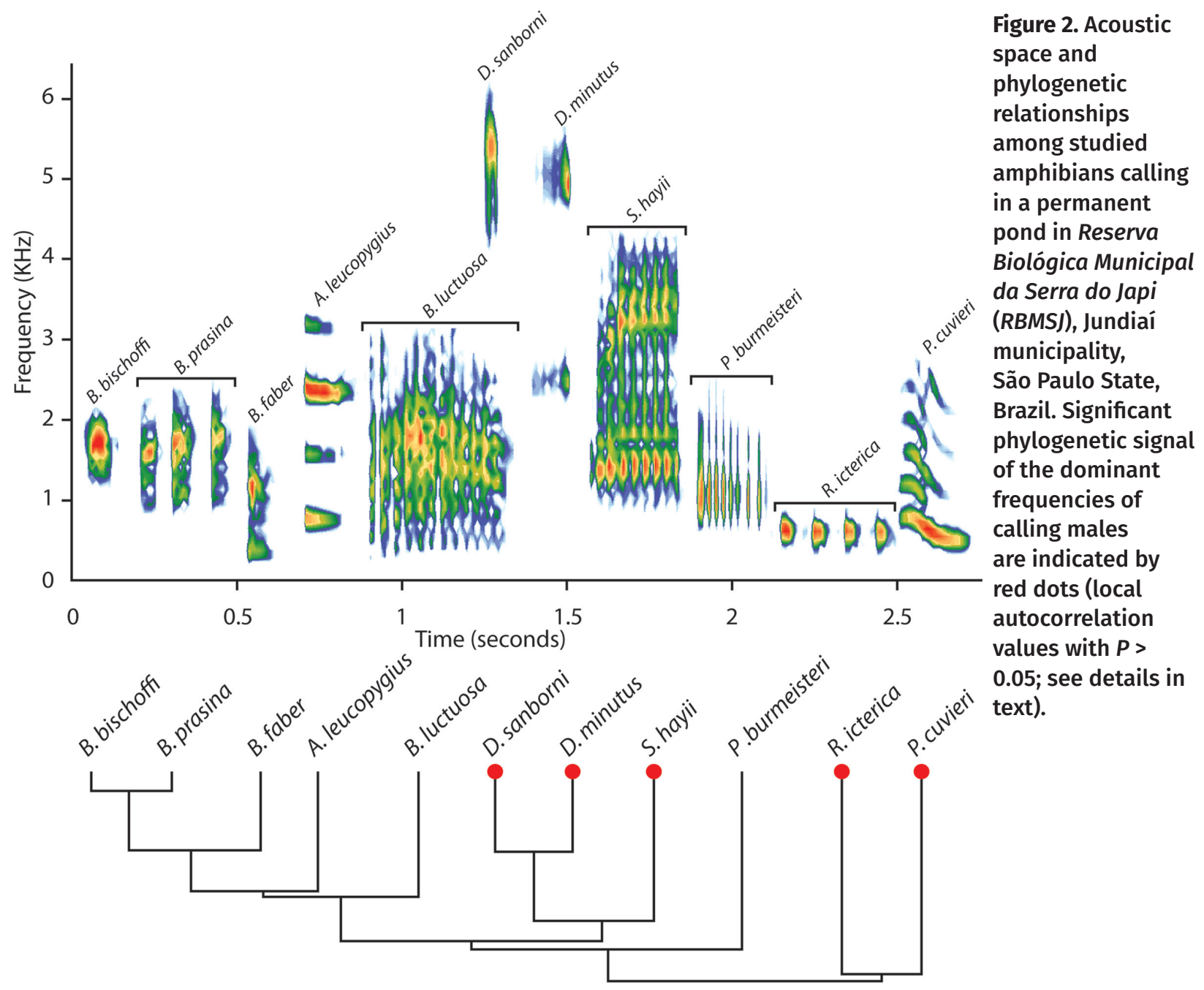


those expected by chance. Our results show there seems to be no more or less overlap in all dimensions of the acoustic niche of the studied community (Table II), which can indicate the absence of character displacement or resource partitioning. Such processes are suggested by some studies as conditions for species coexistence (Rossa-Feres \& Jim 2001, Schmidt et al. 2013), as they decrease competition for resources. Resources partitioning for example is observed in frog communities and results in less niche overlap in one or more niche dimensions to avoid a total overlap among the individuals, and consequently the competitive exclusion (e.g. Conte \& Machado 2005, Prado \& Pombal 2005, Martins et al. 2006).

On the other hand, it has been also suggested that chorus systems could be structured not only by competition and resource partitioning, processes more related to the differentiation of reproductive parameters, but also by the similarity of acoustic traits. In this case, by sharing the same place, the species may be subject to the same selective pressures in the environment (Cardoso \& Price 2010, Tobias et al.
2014), and choruses would form communication networks presenting species with call signals mostly similar to each other (Tobias et al. 2014).

Our first results are related to the seasonal variation in species richness and abundance in the studied community. We observed the greatest richness between September and November, and the negative influence of air temperature, although air humidity did not seem to influence this measure of diversity. Similar results are pointed out in a tropical and subtemperate frog communities (Conte \& Machado 2005, Ximenez \& Tozetti 2015, Guerra et al. 2020). Regarding to the daily period, most species concentrate their calling activity between 8:00 p.m. and 2:00 a.m., as demonstrated in other studies as the period of greater calling activity of anurans throughout different communities (e.g. Haddad 1991, Vasconcelos \& Rossa-Feres 2005). We observed during those periods not only the greatest richness but also a greater abundance of individuals (see Figure 1). Environmental determinants of optimum calling activity could explain overlap in calling period, since we observed a significant relationship between

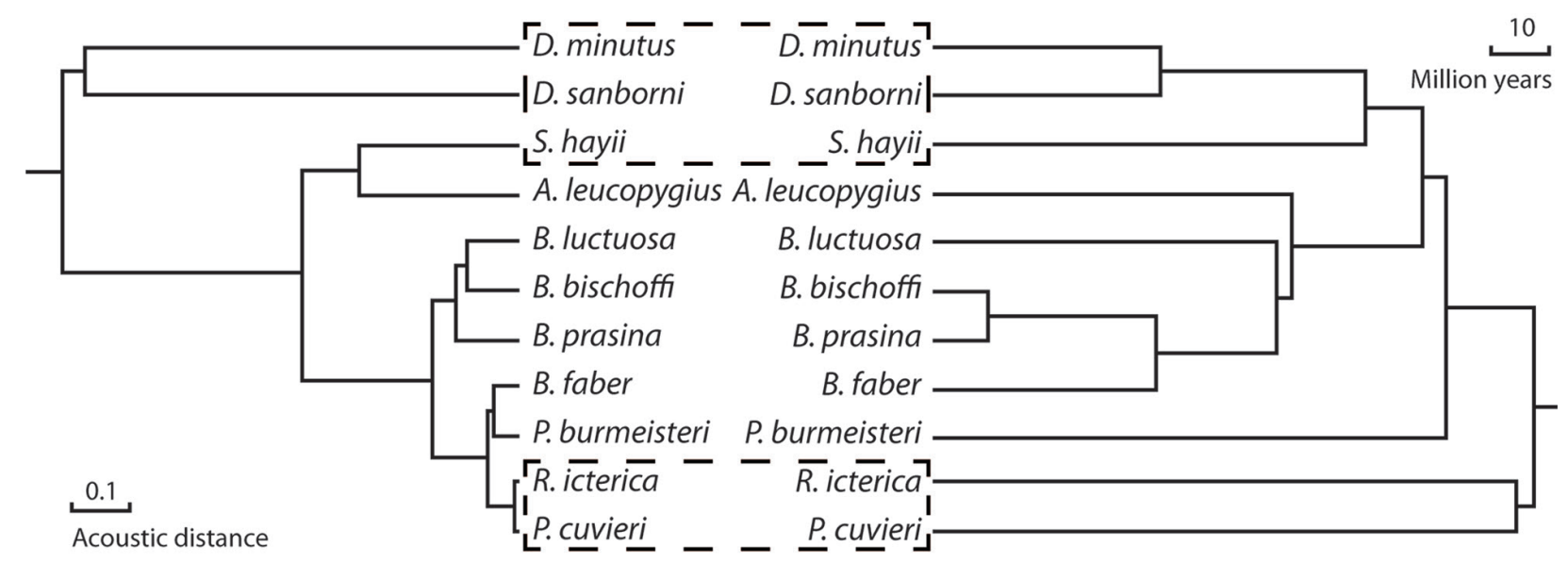

Figure 3. Acoustic distances and phylogenetic relationships of calling males recorded in a permanent pond in Reserva Biológica Municipal da Serra do Japi (RBMSJ), Jundiaí municipality, São Paulo State, Brazil. Dendrogram of acoustic distances based on pairwise niche distance matrix of dominant frequencies. Black dashed squares indicate phylogenetic signal for this trait. Abbreviations for genera corresponds to: Aplastodiscus (A. leucopygius), Boana (B. bischoffi, B. faber, B. prasina), Bokermannohyla (B. luctuosa), Dendropsophus (D. minutus, D. sanborni), Phyllomedusa (P. burmeisteri), Physalaemus (P. cuvieri), Rhinella (R. icterica), and Scinax (S. hayii). 
both species richness and abundance with air temperature, as already recorded in similar studies (e.g. Parris 2004, Kopp et al. 2010, Guerra et al. 2020). Climatic conditions should then act as an environmental filter, synchronizing the calling period of most species in communities of anuran amphibians.

The calling site was not shared among species, and no clear pattern of substrate use was observed (see Table I). We assume that competition and resource partitioning would occur only when such resources are limited and, although we have not measured the availability of calling sites, we suggest that this resource was not limited. This could be related to the complexity of vegetation structure typically observed throughout the Atlantic Forest, as well as the high availability of microhabitats and/or ecological plasticity of species (see Rossa-Feres \& Jim 2001, Zina et al. 2007, Oliveira \& Eterovick 2010, Foerster 2014). Another important factor related to the use of the calling sites, that was not considered by our study, could be the distance of the calling male in relation to the nearest neighbor. Few studies pointed the distance from the neighbors as an important condition to the calling activity (Lingnau \& Bastos 2007, Alcantara et al. 2007, Tárano 2009), and we suggest that future studies consider this variable.

Regarding to the acoustic dimension, species in our studied community showed dominant frequencies ranging from $600 \mathrm{~Hz}$ to $5250 \mathrm{~Hz}$ (Table I; Figure 2). We observed phylogenetic signal in two out of five clades: one containing Scinax hayii, Dendropsophus minutus, D. sanborni, and other including Rhinella icterica and Physalaemus cuvieri (Figure 2). We predict that advertisement calls must be phylogenetic constrained among acoustic niche dimensions because it represents an important pre-zygotic barrier among related species. On the other hand, phylogenetically conserved signals could be contributing to interspecific competition among species, corroborating the idea of social organization in acoustic choruses (Tobias et al. 2014). Therefore, dominant frequency of advertisement calls was constrained by phylogenetic relationships indicating that they affect the partitioning and use of acoustic resources. We then suggest that including the phylogenetic relationships in studies on niche overlap and resources partitioning could be important to explain at least in part the evolutionary history of anuran assemblages.

Because of the influence of environmental and phylogenetic factors in the acoustic niche, we suggest that more variables be included, both in the description of the niche in anuran communities, and in the possible aspects that influence it. Future studies could add different features in acoustic niche, taking questions related to competition and resources partitioning to the reproductive niche level. In that case, we recommend that dimensions related to oviposition site and vocalization substrate should be included, for example. It would also be interesting to explore other factors (e.g. presence of predators, distance from other ponds) that can influence the reproductive activity in communities of frogs, since the calling activity can attract predators.

In conclusion, we observed that these dimensions of the acoustic niche are influenced by different factors, and the resources partitioning does not seem to structure our studied community. By exploring three dimensions of the acoustic niche we observe how each one responds to different aspects, whether ecological or evolutionary. Calling period seems to be constrained by environmental conditions and species physiology, whereas calling site would be used according to environmental availability, although other biotic aspects such as abundance of males and distance from 
the nearest neighbor should be considered. Advertisement calls, on the other hand, seem to reflect at least in part the evolutionary history of the species pool, and can provide insights on the role of the phylogenetic relationships in the partitioning and use of acoustic resources, an important dimension of a reproductive activity in anurans communities.

\section{Acknowledgments}

We thank DG Chagas for helping during the field work; RC Duarte, MBC Godinho, D Almeida-Silva, TJ Portillo, DB Provete, TG Souza, MV Garey, L Sayuri, DC RossaFeres, CT Castanho, and FR Amaral for suggestions in first versions of the manuscript; C. de C. Nogueira for English revision; Rebio Serra do Japi (006/2015), Sisbio/ ICMBio (51226-1), and Ethics Committee in Research (CEUA, Federal University of São Paulo, n 9878020715) for collecting and fieldwork permits; and Coordenação de Aperfeiçoamento de Pessoal de Nivel Superior - CAPES (Finance Code 001), Conselho Nacional de Desenvolvimento Científico e Tecnológico - CNPq (Proc. 405447/2016-7 and Proc. 312795/2018-1), and Fundação de Amparo à Pesquisa do Estado de São Paulo FAPESP (Proc. 2014/23677-9, Proc. 2018/04520-2 and Proc. 2019/15218-8) for financial support.

\section{REFERENCES}

ALCANTARA MB, LIMA LP \& BASTOS RP. 2007. Breeding activity of Scinax centralis (Anura, Hylidae) in Central Brazil. Série Zoologia 97(4): 406-410.

BERTOLUCI J \& RODRIGUES MT. 2002. Utilização de hábitats reprodutivos e micro-hábitats de vocalização em uma taxocenose de anuros (Amphibia) da Mata Atlântica do sudeste do Brasil. Pap Avulsos Zool 42(11): 287-297.

BLOMBERG SP \& GARLAND JR T. 2002. Tempo and mode in evolution: phylogenetic inertia, adaptation and comparative methods. J Evol Biol 15: 899-910.

BOSCH J \& MÁRQUEZ R. 1996. Acoustic competition in male midwife toads Alytes obstetricans and Alytes cisternasii: response to neighbor size and calling rate. implications for female choice. Ethology 102: 841-855.

CARDOSO GC \& PRICE TD. 2010. Community convergence in bird song. Evol Ecol 24: 447-461.

CONTE CE \& MACHADO RA. 2005. Riqueza de espécies e distribuição espacial e temporal em comunidade de anuros (Amphibia, Anura) em uma localidade de Tijucas do Sul, Paraná, Brasil. Rev Bras Zool 22(4): 940-948.

CRUMP ML. 2015. Anuran reproductive modes: evolving perspective. J Herpetol 49: 1-16.

ETEROVICK PC \& SAZIMA I. 2000. Structure of an anuran community in a montane meadow in southeastern Brazil: effects of seasonality, habitat, and predation. Amphib-Reptil 21: 439-461.

FIGUEIREDO GT, STORTI LF, LOURENÇO-DE-MORAES R, SHIBATTA OA \& ANJOS L. 2019. Influence of microhabitat on the richness of anuran species: a case study of different landscapes in the Atlantic Forest of southern Brazil. An Acad Bras Cienc 91: e20171023.

FOERSTER NE. 2014. Partilha Acústica, Uso do Sítio de Vocalização e Influência da Heterogeneidade Ambiental em Uma Taxocenose de Anuros em Um Remanescente de Floresta Ombrófila Mista. Masters Dissertation, Universidade Federal do Paraná, Brazil. (Unpublished).

FOERSTER NE \& CONTE CE. 2018. Anuran diversity in an Araucaria Forest fragment and associated grassland area in a sub-tropical region in Brazil. Herpetol Notes 11: 421-428.

GOTELLI NJ \& ELLISON AM. 2013. EcoSimR. Version 1.00. Available in: http://www.uvm.edu/ ngotelli/EcoSim/ Ecosim.html.

GOTELLI NJ, HART EM \& ELLISON AM. 2015. EcoSimR: Null model analysis for ecological data. $\mathrm{R}$ package version 0.1.0.

GRAFE TU. 2005. Anuran choruses as communication networks. In: Animal Communication Networks [McGregor PK (Ed)], Cambridge: Cambridge University Press, p. 277-299.

GUERRA V, COSTA NQ, LLUSIA D, MÁRQUEZ R \& BASTOS RP. 2020. Nightly patterns of calling activity in anuran assemblages of the Cerrado, Brazil. Community Ecol 21: 33-42.

HADDAD CFB. 1991. Ecologia Reprodutiva de uma Comunidade de Anfíbios Anuros na Serra do Japi, Sudeste do Brasil. Doctoral Thesis, Universidade Estadual de Campinas, Brasil.

HADDAD CFB, CARDOSO AJ \& CASTANHO LM. 1990. Hibridação natural entre Bufo ictericus e Bufo crucifer (Amphibia: Anura). Rev Brasil Biol 50: 739-744.

HADDAD CFB \& PRADO CPA. 2005. Reproductive modes in frogs and their unexpected diversity in the Atlantic Forest of Brazil. BioSci 55(3): 207-217. 
HADDAD CFB \& SAWAYA RJ. 2000. Reproductive modes of Atlantic Forest Hylidae frogs: a general overview and the description of a new mode. Biotropica 42: 862-871.

HADDAD CFB, TOLEDO LF, PRADO CPA, LOEBMANN D, GASPARINI JL \& SAZIMA I. 2013. Guia de Anfíbios da Mata Atlântica: diversidade e biologia. São Paulo, Brasil: Anolis Books, $544 \mathrm{p}$.

HUTCHINSON GE. 1957. Concluding Remarks. Cold Spring Harbor Symposia on Quantitative Biology 22: 425-427.

JETZ W \& PYRON RA. 2018. The interplay of past diversification and evolutionary isolation with present imperilment across the amphibian tree of life. Nat Ecol Evol 2: 850-858.

JOMBART T, BALLOUX F \& DRAY S. 2010. Adephylo: New tools for investigating the phylogenetic signal in biological traits. R package version 1.1-11. Bioinformatics 26: 1907-1909.

KECK F, RIMET F, BOUCHEZ A \& FRANC A. 2016. phylosignal: an $\mathrm{R}$ package to measure, test, and explore the phylogenetic signal. R package version 1.2.1. Ecol Evol 6: 2774-2780.

KÖHLER J, JANSEN M, RODRÍGUEZ A, KOK PJR, TOLEDO LF, EMMRICH M, GLAW F, HADDAD CFB, RÖDEL MO \& VENCES M. 2017. The use of bioacoustics in anuran taxonomy: theory, terminology, methods and recommendations for best practice. Zootaxa 4251: 1-124.

KOPP K, SIGNORELLI L \& BASTOS RR. 2010. Distribuição temporal e diversidade de modos reprodutivos de anfíbios anuros no Parque Nacional das Emas e entorno, estado de Goiás, Brasil. Série Zoologia 100: 192-200.

KRAUSE B. 1987. Bioacoustics, habitat ambience in ecological balance. Whole Earth Rev 57: 14-18.

LAB OF ORNITHOLOGY, CORNELL UNIVERSITY. 2014. Bioacoustics Research Program. Raven Pro: Interactive Sound Analysis Software. Version 1.5. Ithaca, NY: The Cornell Lab of Ornithology. Available in: http://www. birds.cornell.edu/raven.

LINGNAU R \& BASTOS RP. 2007. Vocalizations of the Brazilian torrent frog Hylodes heyeri (Anura: Hylodidae): Repertoire and influence of air temperature on advertisement call variation. J Nat Hist 41(17-20): 1227-1235.

MARTINS IA, ALMEIDA SC \& JIM J. 2006. Calling sites and acoustic partitioning in species of the Hyla nana and rubicundula groups (Anura, Hylidae). Herpetol J 16: 239-247.

MYERS N, MITTERMEIER RA, MITTERMEIER CG, FONSECA GAB \& KENT J. 2000. Biodiversity hotspots for conservation priorities. Nature 403: 853-858.
OKSANEN J ET AL. 2019. Vegan: Community Ecology Package. R package version 2.5-5. https://CRAN.R-project.org/ package=vegan .

OLIVEIRA FFR \& ETEROVICK PC. 2010. Patterns of spatial distribution and microhabitat use by syntopic anuran species along permanent lotic ecosystems in the cerrado of Southeastern Brazil. Herpetologica 66: 159-171.

PARADIS E, CLAUDE J \& STRIMMER K. 2004. APE: analyses of phylogenetics and evolution in $\mathrm{R}$ language. $\mathrm{R}$ package version 5.1. Bioinformatics 20: 289-290.

PARRIS KM. 2004. Environmental and spatial variables influence the composition of frog assemblages in subtropical eastern Australia. Ecography 27(3): 392-400.

PIJANOWSKI BC, VILLANUEVA-RIVERA LJ, DUMYAHN SL, FARINA A, KRAUSE BL, NAPOLETANO BM, GAGE SH \& PIERETTI N. 2011. The science of sound in the landscape. BioScience 61: 203-216.

PINTO HS. 1992. Clima da Serra do Japi. In: História natural da Serra do Japi: Ecologia e preservação de uma área florestal no sudeste do Brasil [Morellato LPC (Org)], Campinas: Editora da Unicamp/Fapesp, p. 30-38.

PRADO CPA, UETANABARO M \& HADDAD CFB. 2005. Breeding activity patterns, reproductive modes, and habitat use by anurans (Amphibia) in a seasonal environment in the Pantanal, Brazil. Amphib-Reptil 26: 211-221.

PRADO GM \& POMBAL JR JP. 2005. Distribuição espacial e temporal dos anuros em um brejo da Reserva Biológica de Duas Bocas, sudeste do Brasil. Arq Mus Nac Rio de J 63(4): 685-705.

R CORE TEAM. 2018. R: A language and environment for statistical computing. R Foundation for Statistical Computing. Version 3.4.4. Available from: http://www.Rproject.org/.

RESENDE CL, SCARANO FR, ASSAD ED, JOLY CA, METZGER JP, STRASSBURG BBN, TABARELLI M, FONSECA GA \& MITTERMEIER RA. 2018. From hotspot to hopespot: An opportunity for the Brazilian Atlantic Forest. Perspect Ecol Conserv 16: 208-214.

RIBEIRO MC, METZGER JP, MARTENSEN AC, PONZONI FJ \& HIROTA MM. 2009. The Brazilian Atlantic Forest: how much is left, and how is the remaining forest distributed? Implications for conservation. Biol Conserv 142: 1141-1153.

ROSSA-FERES DC \& JIM J. 2001. Similaridade do sítio de vocalização em uma comunidade de anfíbios anuros na região noroeste do Estado de São Paulo, Brasil. Rev Bras Zoo 18: 439-454. 
ROSSA-FERES DC, SAWAYA RJ, FAIVOVICH J, GIOVANELLI JGR, BRASILEIRO CA, SCHIESARI L, ALEXANDRINO J \& HADDAD CFB. 2011. Anfíbios do estado de São Paulo, Brasil: conhecimento atual e perspectivas. Biota Neotrop 11: 47-66.

SCHMIDT AKD, RÖMER H \& KLAUS R. 2013. Spectral niche segregation and community organization in a tropical cricket assemblage. Behav Ecol 24: 470-480.

SCHOENER TW. 1974. Resource partitioning in ecological communities. Science 185: 27-39.

SILVA FR, ALMEIDA-NETO M, PRADO VHM, HADDAD CFB \& ROSSAFERES DC. 2012. Humidity levels drive reproductive modes and phylogenetic diversity of amphibians in the Brazilian Atlantic Forest. J Biogeogr 39: 1720-1732.

SINSCH U, LÜMKEMANN K, ROSAR K, SCHWARZ C \& DEHLING $J M$. Acoustic niche partitioning in an anuran community inhabiting an Afromontane wetland (Butare, Rwanda). 2012. Afr Zool 47(1): 60-73.

TÁRANO Z. 2009. Structure of transient vocal assemblages of Physalaemus fischeri (Anura, Leiuperidae): calling site fidelity and spatial distribution of males. S Am J Herpetol 4(1): 43-50.

TOBIAS JA, PLANQUÉ R, CRAM DL \& SEDDON N. 2014. Species interactions and the structure of complex communication networks. PNAS 111: 1020-1025.

VASCONCELOS TS \& ROSSA-FERES DC. 2005. Diversidade, distribuição espacial e temporal de anfíbios anuros (Amphibia, Anura) na região noroeste do estado de São Paulo, Brasil. Biota Neotrop 5(2): 1-14.

VASCONCELOS TS \& ROSSA-FERES DC. 2008. Habitat heterogeneity and use of physical and acoustic space in anuran communities in Southeastern Brazil. Phyllomedusa 7(2): 127-142.

WELLS KD. 1977. The social behavior of anuran amphibians. Anim Behav 25: 666-693.

WELLS KD. 2007. The ecology and behavior of amphibians. Chicago London: The University of Chicago Press, 857 p.

WIENS JJ \& GRAHAM CH. 2005. Niche conservatism: integrating evolution, ecology, and conservation biology. Ann Rev Ecol Evol Syst 36: 519-539.

WIENS JJ ET AL. 2010. Niche conservatism as an emerging principle in ecology and conservation biology. Ecol Lett 13: $1310-1324$.

XIMENEZ SS \& TOZETTI AM. 2015. Seasonality in anuran activity and calling season in a Brazilian subtemperate wetland. Zool Stud 54: 47.
ZINA J, ENNSER J, PINHEIRO SCP, HADDAD CFB \& TOLEDO LF. 2007. Taxocenose de anuros de uma mata semidecídua do interior do Estado de São Paulo e comparações com outras taxocenoses do Estado, sudeste do Brasil. Biota Neotrop 7(2): 49-57.

\section{How to cite}

MANZANO MCR \& SAWAYA RJ. 2022. Environmental and phylogenetic aspects affect in different ways the acoustic niche of a frog community in southeastern Brazil. An Acad Bras Cienc 94: e20200705. DOI 10.1590/0001-3765202220200705.

Manuscript received on May 12, 2020;

accepted for publication on October 12, 2020

MARIA CAROLINA R. MANZANO ${ }^{1,2}$

https://orcid.org/0000-0003-0464-9029

\section{RICARDO J. SAWAYA ${ }^{3}$}

https://orcid.org/ 0000-0003-1897-1836

${ }^{1}$ Programa de Pós-Graduação em Evolução e Diversidade, Universidade Federal do ABC/UFABC, Alameda da Universidade, s/n, Anchieta, 09606045 São Bernardo do Campo, SP, Brazil

${ }^{2}$ Universidade Federal de São Paulo, UNIFESP, Departamento de Ecologia e Biologia Evolutiva, Rua Prof. Artur Riedel, 275, Jd. Eldorado, 09972-270 Diadema, SP, Brazil

${ }^{3}$ Universidade Federal do ABC/UFABC, Centro de Ciências Naturais e Humanas, Alameda da Universidade, s/n, Anchieta, 09606-045 São Bernardo do Campo, SP, Brazil

Correspondence to: Maria Carolina Rodella Manzano

E-mail:carolrmanzano@gmail.com

\section{Author contributions}

MCRM and RJS idealized the project, MCRM collected data in the field and analyzed data. Both authors interpreted the results and wrote the manuscript.

\section{(cc) BY}

